\title{
Upaya untuk mengurangi preparasi gigi: Fung shell bridge
}

\author{
Eri H. Jubhari \\ Bagian Prostodonsia \\ Fakultas Kedokteran Gigi Universitas Hasanuddin
}

\begin{abstract}
Natural tooth can be replaced with many ways, for example with bridge. This kind of denture is conventional because too much sound teeth tissue are grinded. Therefore, many designs which grinds as minimal as possible have been tried such as Maryland and Rochette designs. As technology develops, Fung Shell System was found. It consists of one unit bridge called pontic which has a form of porcelain fused to metal and post bridge. Fung bridge is easier and faster to make than conventional bridge. This article is expected to enrich our knowledge of fung bridge which is as modification of bridge.
\end{abstract}

Key words: preparation of abutment, fung shell bridge

\begin{abstract}
ABSTRAK
Gigi alami yang telah dicabut dapat diganti dengan berbagai cara, antara lain dengan menggunakan gigitiruan jembatan (GTJ). Gigitiruan jenis ini dikatakan konvensional karena dianggap terlalu banyak membuang jaringan gigi yang sehat. Oleh karena itu berbagai cara diusahakan untuk membuat GTJ yang mengasah jaringan gigi seminimal mungkin. Hal tersebut dicapai dengan desain GTJ Rochette dan Maryland. Tetapi seiring dengan kemajuan teknologi ditemukan lagi suatu sistem baru yang disebut Fung Shell System. Fung bridge adalah suatu GTJ yang terdiri dari satu unit bridge, yang meliputi pontik berupa porcelain fused to metal dan post bridge. Pembuatan fung bridge ini relatif lebih mudah dan cepat dibandingkan dengan teknik konvensional. Karya ilmiah ini diharapkan menambah wawasan dan pengetahuan tentang Fung Shell System dan Fung Bridge sebagai modifikasi GTJ.
\end{abstract}

Kata kunci: preparasi gigi penyangga, fung shell bridge 
Koresponden: $\quad$ Eri H. Jubhari, Jl. Kandea No.5, Makassar, Indonesia. E-mail: erihjubhari@lycos.com

\section{PENDAHULUAN}

Kehilangan gigi biasa disebabkan oleh beberapa hal, antara lain trauma, karies, penyakit periodontal, dan iatrogenik.1 Kehilangan gigi akan menyebabkan gangguan fungsi fonetik, mastikasi, dan estetik serta menyebabkan perubahan lingir alveolar. Setelah pencabutan gigi alami, struktur lingir alveolar mengalami perubahan akibat adanya resorbsi. Resorbsi alveolar merupakan proses yang berjalan terus yang akhirnya menyebabkan perubahan morfologi tulang sehingga mempengaruhi retensi gigitiruan.2

Untuk memperbaiki gangguan fungsi di atas, maka kehilangan gigi tersebut harus digantikan dengan gigitiruan. Secara umum gigitiruan dapat dibedakan atas gigitiruan lepasan dan gigitiruan jembatan/cekat.

Pasien cenderung memilih gigitiruan jembatan untuk menggantikan giginya yang hilang karena memiliki konstruksi yang paling baik dan hanya menutupi sedikit jaringan penyangga. Umumnya gigitiruan ini dibuat dengan melakukan preparasi pada sebagian besar struktur gigi penyangganya. Adanya keharusan untuk melakukan preparasi inilah yang seringkali menjadi bahan pemikiran bagi pasien untuk memilih gigitiruan yang terbaik baginya. Hal ini disebabkan karena akan mengorbankan gigi yang sehat untuk dipreparasi, terutama bila gigi tersebut masih utuh.3

Untuk itu dikembangkanlah suatu teknik baru yang masih menggunakan prinsip preparasi dalam pembuatan gigitiruan jembatan, dengan desain preparasi yang sangat minimal.3 Pada awalnya telah ditemukan suatu sistem preparasi disebut Maryland bridge dengan preparasi yang minimal dan retensi yang diperoleh dari teknik etsa asam. Tetapi seiring dengan kemajuan teknologi kemudian ditemukan lagi suatu sistem yang disebut Fung Shell System.

Fung Shell System ini terdiri dari Fung Crowns, Fung Caps, Fung Bridge, dan Fung Inlays. Fung bridge adalah suatu gigitiruan jembatan satu unit, yang meliputi pontik berupa porcelain fused to metal dan post bridge. Pembuatan fung bridge ini relatif lebih mudah dan cepat dibandingkan dengan teknik konvensional.4

Tujuan penulisan karya ilmiah ini adalah untuk mendapatkan pemahaman tentang Fung Shell System dan Fung Bridge, 
serta pengetahuan tentang penatalaksanaan Fung Bridge di klinik.

\section{TINJAUAN PUSTAKA}

\section{Gigitiruan Jembatan}

Gigitiruan jembatan adalah suatu gigitiruan yang menggantikan satu atau lebih gigi asli yang hilang, disemen pada gigi asli yang telah dipreparasi. Daya kunyah sebagian besar diteruskan ke gigi penyangga serta jaringan periodonsiumnya. Tujuan pembuatan gigitiruan jembatan adalah mengembalikan fungsi pengunyahan, memperbaiki penampilan dan fungsi bicara, memelihara kesehatan gigi, serta mencegah gangguan pada sendi temporomandibula.3

Indikasi pembuatan gigitiruan jembatan adalah kehilangan satu atau lebih gigi, gigi yang memerlukan restorasi, kurangnya celah karena pergeseran gigi tetangga ke daerah edentulus, gigi di sebelah daerah edentulus miring, splint bagi gigi yang mengalami kelainan jaringan periodontal, gigi yang memiliki ketebalan email yang cukup untuk dietsa.3 Kontraindikasinya adalah pasien yang tidak koperatif, kondisi kejiwaan pasien kurang menunjang, kelainan jaringan periodonsium, prognosis yang jelek dari gigi penyangga, diastema yang panjang, kemungkinan kehilangan gigi pada lengkung yang sama, dan resorbsi lingir alveolus yang besar pada daerah anodonsia.3

Keuntungan gigitiruan jembatan adalah memiliki stabilitas yang baik, tidak menyebabkan retensi makanan, tidak mempunyai cengkeram, dapat menyebarkan tekanan fungsional ke seluruh gigi penyangga, memiliki estetik yang baik, pasien mudah beradaptasi.3,5,6 Kerugiannya adalah tampaknya logam pada gigitiruan yang terbuat dari kombinasi bahan logam, usia pemakai terbatas antara 20-55 tahun, perlu pemeliharaan gigitiruan yang lebih telaten, perlu pengasahan pada gigi alami, dan memerlukan biaya yang relatif lebih besar besar dibandingkan gigituan lepasan.

\section{Macam-macam GTJ}

Ada empat desain dasar gigitiruan jembatan yang perbedaannya terletak pada dukungan yang ada pada masing-masing ujung pontik. Keempat desain ini adalah gigitiruan jembatan lekat (fixed-fixed bridge), setengah lekat (semi-fixed bridge), lekat sebelah (cantilever bridge), dan konektor panjang (spring cantilever bridge). Keempat desain di atas dapat dikombinasikan antara satu dengan yang lain dan disebut gigitiruan jembatan gabungan (compound bridge).7 Gigitiruan jembatan umumnya terdiri dari beberapa 
komponen, yakni pontik, retainer, konektor, span/saddle, dan pier.3,5,8

Seiring dengan berkembangnya bahan, utamanya semen adesif, maka dikembangkan pula gigitiruan jembatan adesif. Gigitiruan adesif ini juga terdiri dari satu pontik dan dua retainer, dengan retainer berupa sayap yang berjalan dari proksimal pontik dan lingual/palatal. Cara insersinya tidak menggunakan zinc phosphate cement, namun menggunakan resin adesif. Gigitiruan jembatan adesif ini terdiri atas dua macam yaitu gigitiruan jembatan Rochette dan Maryland.3,9

Gigitiruan jembatan Maryland adalah suatu gigitiruan cekat yang retainernya berupa sayap dari logam yang dietsa dengan asam dan dilekatkan dengan menggunakan resin komposit pada gigi penyangga yang telah dietsa. Preparasinya hanya meliputi daerah proksimal dan lingual dengan pengambilan jaringan email yang sedikit.5

Gigitiruan jembatan Maryland dapat digunakan untuk restorasi gigi anterior maupun posterior. Dalam memilih perawatan yang akan digunakan harus dipertimbangkan keadaan email, jaringan periodontal dan morfologi gigi penyangga. 10

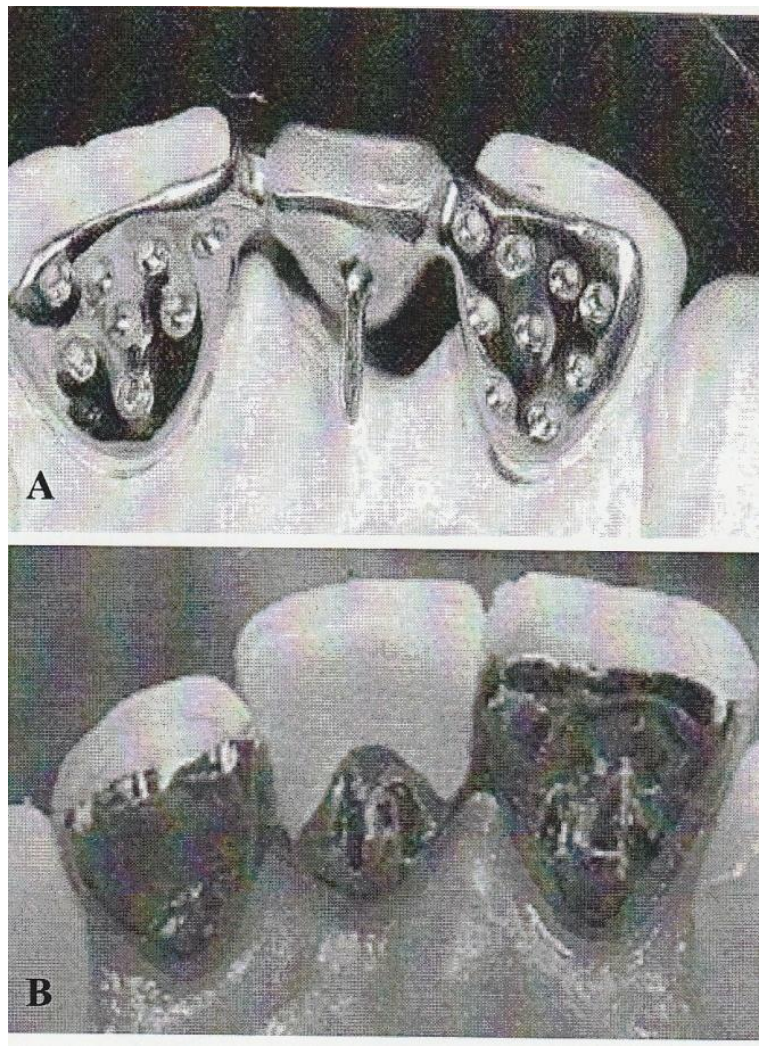

Gambar 1. A. GTJ Rochette B. GTJ Maryland. (Sumber: Dale GB. Esthetic dentistry: Adhesive resin bonded cast restorations. Philadhelphia: Lea \& Febiger; 1993.p.1546)14

\section{Indikasi dan Kontraindikasi}

Indikasi : pada pasien muda, lapisan email yang masih kuat, gigi penyangga berada di dalam lengkung rahang, tinggi mahkota klinis yang cukup, yaitu cukup untuk memberikan retensi yang baik dalam hal ini perbandingan antara mahkota dan akar adalah 1:2, sebagai backing pada gigi asli 
yang fraktur, untuk dikombinasi dengan restorasi lain. 13

Kontraindikasi: Email yang sudah mengalami karies atau tambalan yang besar, gigi malposisi, mahkota klinis yang pendek, pada kondisi email yang buruk, misalnya pada email yang mudah rapuh. 13

\section{Fung Shell System}

Fung shell system adalah suatu sistem yang digunakan pada restorasi porselen dengan kualitas kelas satu, semi otomatis dan biaya relatif murah. Fung shell system dibedakan atas fung bridge, fung crown, fung inlay, dan fung cap. Keempat restorasi ini didesain dengan pengasahan gigi yang minimal, serta sangat ideal untuk perawatan dengan teknik konservatif tinggi.4
Langkah singkat dari pembuatan mahkota dengan menggunakan fung shell system yaitu memilih ukuran prefabricated crown yang sesuai dengan jenis mahkota yang akan dibuat, mencocokkan prefabricated crown tersebut pada model gips, memotong prefabricated crown sesuai dengan bentuk mahkota yang akan dibuat, menambahkan campuran dentin baru dengan air, mengeringkan porselen untuk mengeluarkan kelebihan air, memotong kelebihan porselen yang terbentuk, mempersiapkan pembakaran. 4

\section{Fung Bridge}

Fung bridge adalah suatu gigitiruan jembatan yang terdiri dari satu unit bridge, yang meliputi pontik berupa porcelain fused to metal dan post bridge. 4

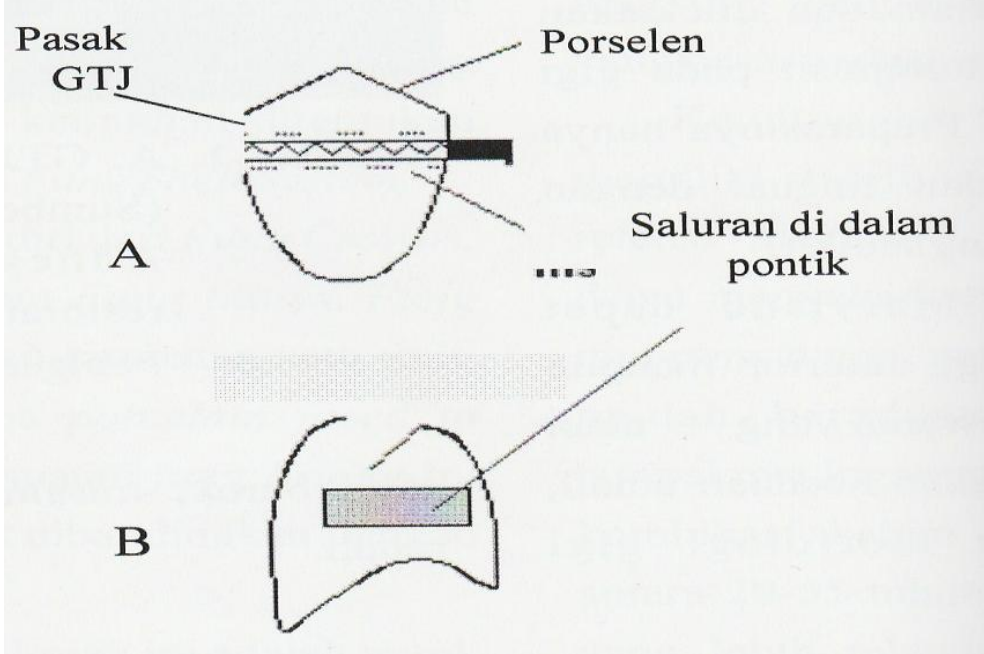

Gambar 2. Fung bridge. A. Tampakan lingual B. tampakan bukal. (Sumber : Fung shell system. Available at http//www.fung-international.com. diakses 15 April 2004)4 
Fung bridge dapat juga disebut sebagai gigitiruan jembatan pengurang tekanan (gigitiruan fungsional), karena tekanan yang diakibatkan oleh penggunaan gigitiruan jembatan lekat dalam waktu lama dapat menyebabkan kerusakan pada gigi penyangga, didesain sebagai pengganti fixed-fixed bridge untuk penggunaan dalam waktu lama, dan penghubungnya (joint) memungkinkan gigitiruan jembatan bergerak naik dan turun, serta miring ke arah bukal dan lingual. Selanjutnya, penghubung yang didesain khusus ini sesuai untuk beragam bahan tumpatan dengan maksud memungkinkan terjadinya beragam tingkatan gerakan fungsional, misalnya komposit swapolimerisasi yang memungkinkan gerakan yang minimal, nilon yang memungkinkan pergerakan yang lebih banyak, dan bahan plastik lunak yang memungkinkan pergerakan yang lebih banyak lagi. Selain itu, dianjurkan untuk mengganti penghubung gigitiruan jembatan fungsional ini setiap beberapa tahun karena pergerakan pontik menjadi berlebihan akibat ausnya bahan penghubung yang disebabkan oleh tekanan, penggantian penghubung ini jauh lebih mudah daripada memperbaiki gigi penyangga yang mengalami kerusakan, seperti pada kasus gigitiruan jembatan lekat, yang sering mengharuskan pencabutan pada gigi penyangga. 4

\section{Indikasi}

Indikasi pembuatan fung bridge adalah gigitiruan jembatan yang akan digunakan dalam waktu lama, gigi penyangga yang mengalami karies, terutama di bagian bukoproksimal, dan pontik menyerupai bentuk gigi kaninus. 4

\section{Keuntungan Fung Bridge}

Adapun keuntungan dari Fung bridge adalah pemotongan prefabricated fung bridge yang mudah tanpa menyebabkan keretakan porselen, pengurangan gigi yang minimal tanpa menampakkan struktur logam, tidak membutuhkan perlengkapan yang mahal maupun keterampilan khusus, penyelesaian yang jauh lebih mudah dan cepat dibandingkan dengan teknik konvensional. Selain itu, pengasahan gigi penyangga tidak terlalu banyak, sangat memuaskan pasien dan biayanya relatif lebih murah, dapat dibuat pada gigi penyangga yang divergen dan pada gigi depan, dan tidak membutuhkan jadwal kunjungan secara berulang.4 


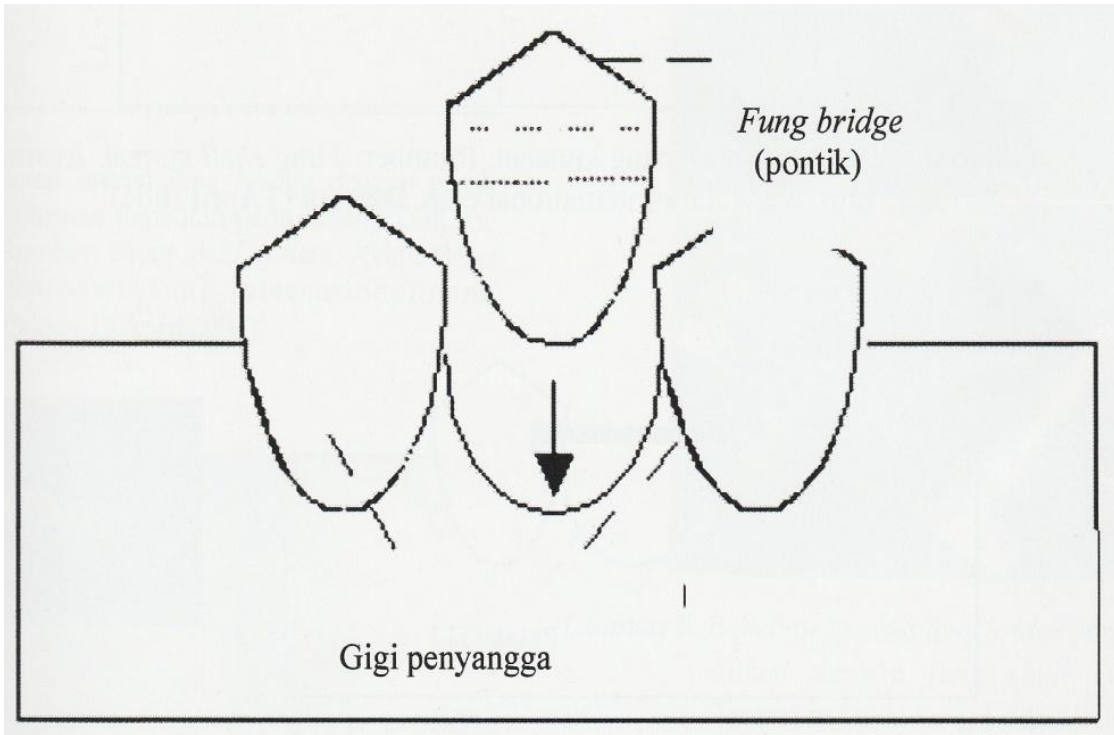

Gambar 3. Tahap mencobakan tanpa pasak. (Sumber: Fung shell system. Available at :http//www.fung-international.com.Diakses 15 april 2004)4

\section{Tahap Pembuatan Fung Bridge}

\section{Konsultasi awal4}

Pada kunjungan pertama ini, dilakukan pencetakan gigi rahang atas dan ahang bawah dengan alginat, dicor dengan gips keras. Selanjutnya model dan keterangan mengenai warna gigi dikirim ke laboratorium untuk proses lebih lanjut.

\section{Kunjungan kedua}

Dilakukan pencobaan pontik fung bridge tanpa pasak. Setelah itu daerah pemotongan lubang kuncian ditandai pada gigi penyangga.
Pemotongan lubang kuncian dilakukan dengan menggunakan diamond inverted cone long bur (807/014). Pengambilan dilakukan dari arah proksimal ke bukal. Hendaknya jangan melakukan pengambilan ke arah lingual.

Mencobakan pasaknya tanpa fung bridge. Setelah itu, dilanjutkan dengan mencobakan pontik fung bridge bersama dengan pasak gigitiruan jembatan pada lubang penyangga. Setelah itu, dilakukan pemeriksaan oklusi sentris. 


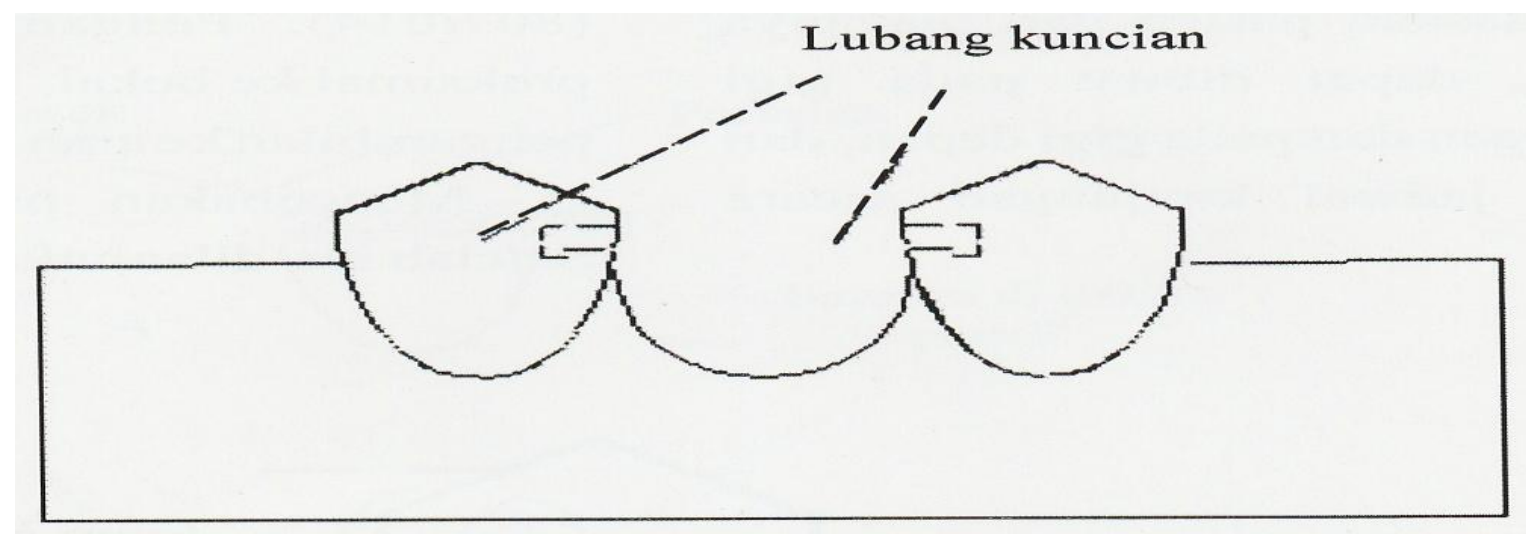

Gambar 4. Pemotongan lubang kuncian. (Sumber: Fung shell system. Available at http//www.fung-international.com. diakses 15 April 2004).4
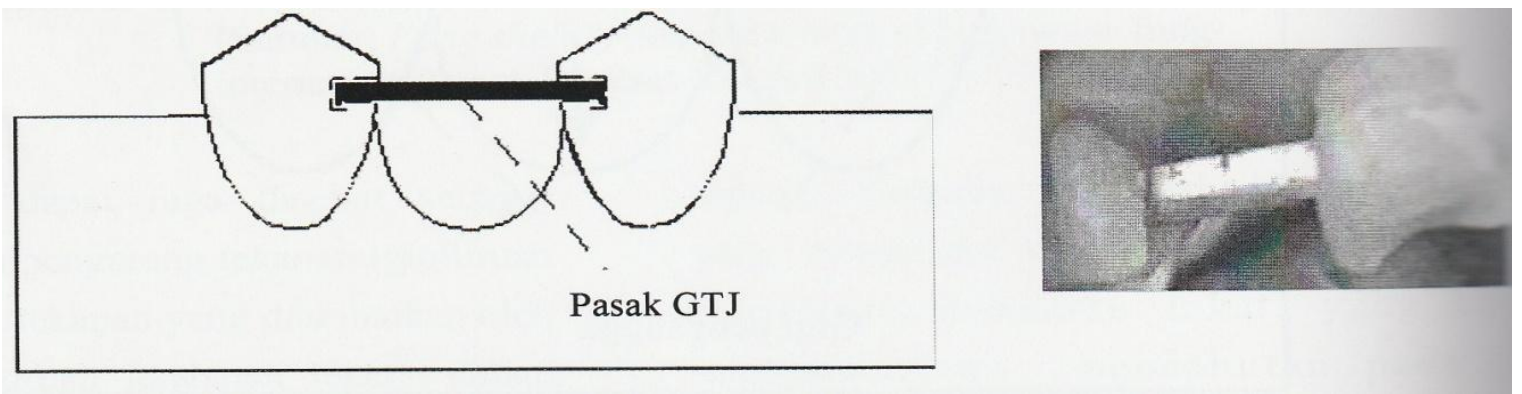

Gambar 5. A dan B. Tahap mencobakan pasak tanpa Fung bridge. (Sumber: Fung shell system. Available at http//www.fung-international.com. diakses 15 April 2004).4

Tahap berikutnya adalah penempatkan bahan tumpatan pada saluran pontik dan pasang pasak gigitiruan jembatan. Selanjutnya dilakukan insersi fung bridge bersama dengan pasak gigitiruan jembatan pada lubang kuncian, kemudian pasien diinstruksikan untuk menggigit pada posisi sentris. Setelah pontik diarahkan pada kedudukan yang tepat, kemudian lakukan curing terhadap bahan tumpatan di dalam saluran pontik.

Fung bridge dikeluarkan bersama dengan pasaknya. Bahan tumpatan baru ditempatkan pada daerah yang dietsa-asam kemudian dilakukan bonding pada lubang penyangga. Fung bridge dipasang kembali pada lubang yang telah disiapkan dengan posisi sentris, kemudian dilakukan curing terhadap bahan tumpatan, dan diakhiri dengan pemotongan kelebihan bahan tumpatan. 


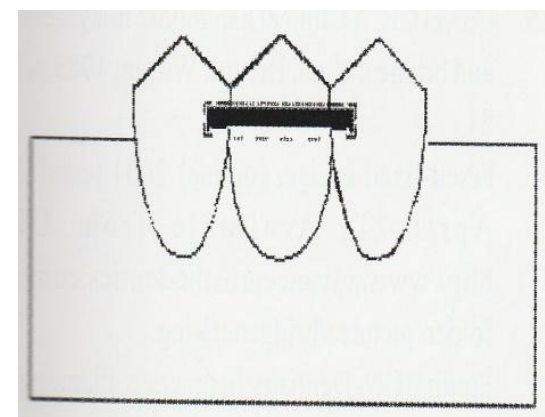

Gambar 6. Tahap Insersi fung bridge dengan pasak gigitiruan jembatan pada lubang kuncian (Sumber: Fung shell system. Available at http//www.funginternational.com. diakses 15 April 2004).4

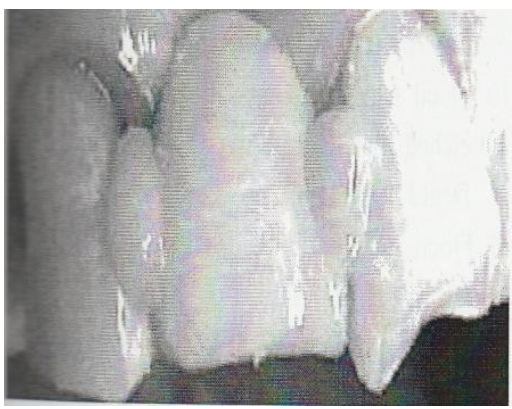

Gambar 7. Tahap sementasi fung bridge (Sumber: Fung shell system. Available at http//www.funginternational.com. diakses 15 April 2004).4
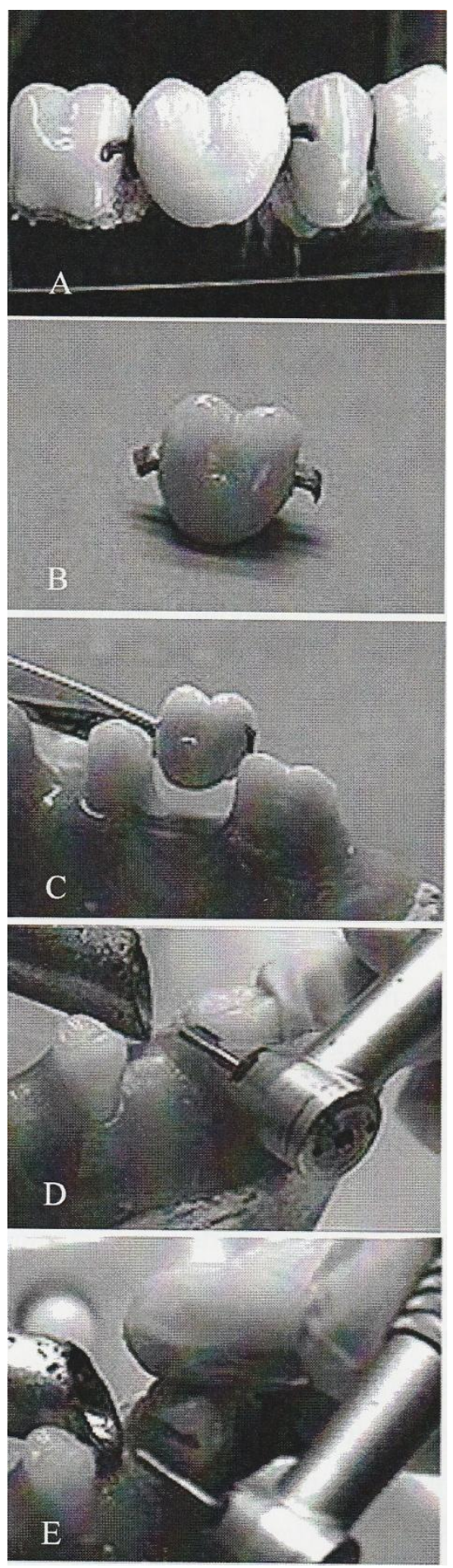

Gambar 8. Beberapa gambar fung bridge porselen yang dibuat dengan fung shell system. A. Tampakan bukal Fung bridge. 
B. Pasak yang bukal fung bridge. C. Tahap mencobakan.

D. Pemotongan lubang kuncian. E. Lubang berbentukL. (Sumber: Fung shell system. Available at http//www.funginternational.com. diakses 15 April 2004).4

\section{PEMBAHASAN}

Salah satu keuntungan memilih gigitiruan jembatan dibandingkan gigitiruan lepasan adalah adaptasi yang lebih baik. Akan tetapi kekurangannya adalah bagian jaringan gigi yang sehat juga akan diasah.

Adanya prinsip ramah lingkungan yang jika diaplikasikan dalam bidang kedokteran gigi adalah hanya membuang jaringan yang tidak dapat diselamatkan dan mempertahankan jaringan yang sehat membuat para klinisi berupaya untuk mempertahankan jaringan gigi sebisa mungkin. Teknik ini sulit dimungkinkan dengan pembuatan gigitiruan jembatan konvensional.

Fung bridge menjawab tantangan tersebut di atas, karena hanya sebagian kecil jaringan gigi yang diasah. Meskipun demikian dari segi kekuatan tidak menyamai kekuatan gigitiruan jembatan konvensional. Untuk diadakan beberapa penyesuaian, misalnya pontik dibuat meyerupai gigi kaninus, dan kontak dengan gigi antagonis dibuat ringan. 4

\section{Cara Pembersihan}

Dalam pemakaian gigitiruan jembatan sangatlah perlu untuk memperhatikan kebersihan gigitiruan tersebut. Adapun cara untuk menjaga kebersihannya adalah dengan melakukan kontrol rutin setiap tiga bulan sekali, membersihkan gigitiruan jembatan dengan menggunakan dental floss dan interdental tip, serta dengan senantiasa menjaga kebersihan dan kesehatan mulut.3

\section{RINGKASAN}

Gigitiruan jembatan merupakan suatu gigitiruan yang menggantikan satu atau lebih gigi asli yang hilang dan disemen pada gigi penyangganya. Umumnya gigitiruan jembatan lebih banyak digunakan karena merupakan konstruksi yang paling baik yaitu hanya menutupi sedikit jaringan.

Pada mulanya gigitiruan jembatan dibuat dengan menggunakan teknik konvensional yaitu dengan melakukan preparasi pada sebagian struktur gigi penyangganya, tetapi seiring dengan perkembangan teknologi maka ditemukan suatu cara baru untuk meminimalkan 
preparasi pada gigi yang disebut sebagai gigitiruan jembatan adesif, yaitu Rochette dan Maryland. Gigitiruan jembatan ini memperoleh retensi dari teknik etsa asam pada gigi penyangganya dan permukaan dalam dari logam.

Setelah gigitiruan jembatan Maryland dianggap sukses dalam mengurangi preparasi pada gigi, kemudian dikembangkan lagi suatu teknik baru yang diberi nama Fung shell system. Sistem fung shell ini dibedakan atas fung bridge, fung crown, fung cap dan fung inlay. Pada fung bridge, preparasi gigi yang dilakukan lebih minimal dibandingkan dengan teknik sebelumnya. Fung bridge memperoleh retensi dari pasak yang terletak pada pontik yang berupa prefabricated crown. Selain preparasi yang lebih minimal, pembuatan fung bridge ini juga lebih mudah.

\section{DAFTAR PUSTAKA}

1. Wyatt CL. The effect of prosthodontic treatment on alveolar bone loss: A review of the literatur. J Prosthet Dent 1998; 80: 362.

2. Fenn HRB, Liddelow KP. Clinical dental prosthetics. 2nd ed. London: Staples Press; 1997. p.217-8.

3. Prajitno HR. Ilmu geligi tiruan jembatan. Jakarta: EGC; 1196.p.1-15.
4. Fung Shell System. [online] 2004 [cited 2004 April 15] Available from URL:http//www.funginternational.com

5. Cowel CR. A Clinical handbook: inlays, crowns and bridges. 4th ed. Bristol: Wright; 1985.p.149-51.

6. Fixed-fixed bridge. [online] 2004 [cited 2004 April 21] Available from URL:

http//www.advanceprosthodontics.com /nss-folder/ pictures/bridgenet1.jpg.

7. Smith BGN. Dentistry in practice: Planning and making crown and bridges. London : Martin Dunitz; 1986.p.131-45.

8. Allan DN. Petunjuk bergambar mahkota dan jembatan. Alih bahasa: Agus Djaya. Jakarta : Hipokrates; 1994. p.81-3.

9. Cantilever bridge. [online] 2004 [cited 2004 May 14] Available from URL: http//www.clinicianschoice.com.

10. Flood AM, Brockhurst P, Harcourt JK. The etched metal/composite resin interface. Aust Dent J 1989; 34: 330-9.

11. Flood AM. Resin-bonded protheses: Clinical guidelines. Aust Dent $\mathrm{J}$ 1989; 34: 209-18.

12. Tregaster JN, Wohlford JM. Tensile strength of three bonding agents for 
resin-bonded prothese. J. Prosthet Dent 1989; 62: 14-7.

13. Clark JW. Provisional restoration in dental material in clinical dentistry. London: John Wright; 1982.p.11-23.

14. Dale GB. Esthetic dentistry: Adhesive resin bonded cast restorations. Philadhelphia: Lea \& Febiger; 1993.p.154-6. 